\title{
The Influence of Labor Taxes on the Migration of Skilled Workers
}

\author{
PETER EGGER \\ DOINA MARIA RADULESCU
}

CESIFO WORKING PAPER NO. 2462

CATEGORY 1: PUBLIC FINANCE

NOVEMBER 2008

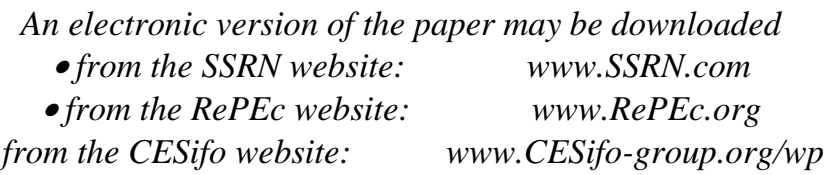




\title{
The Influence of Labor Taxes on the Migration of Skilled Workers
}

\begin{abstract}
This paper investigates empirically the role of taxes on labor for the stock of expatriates and the migration flows of skilled workers. Given the increasing mobility of labour, especially of high-skilled people and expatriates, it is interesting to see to what extent labour income taxes and social security contributions determine migration flows. We collect data on personal income tax profiles for 49 economies and the year 2002. In particular, we determine the component of labor taxes which is borne by employers and the one that is borne by employees, following the OECD's Taxing Wages Approach. For the latter, we calculate the progressivity of personal income tax rates between the average wage and five times the average wage. This may be interpreted as the tax progression which is relevant for well-paid workers. Then, we use the personal income tax variables to estimate their effect on bilateral stocks of expatriates into OECD countries and the migration of skilled workers into these countries. Personal income tax rates turn out to have a robust negative effect on cross-border flows of skilled workers in the OECD.
\end{abstract}

JEL Code: J61, H24, F22.

Keywords: labor taxation, skilled workers, migration, expatriates.

Peter Egger

Ifo Institute for Economic Research at the University of Munich

Poschingerstrasse 5

81679 Munich

Germany

egger@ifo.de
Doina Maria Radulescu

Center for Economic Studies and CESifo

at the University of Munich

Schackstr. 4

80539 Munich

Germany

radulescu@lmu.de

November 24, 2008 


\section{Introduction}

'Taxation can be used as a means of attracting the most highly skilled foreign workers.' (OECD, Recent Trends in International Migration, Paris 2007, p.120)

The increasing mobility of people across international borders - especially the one of highly skilled workers and that of expatriates - raises the question about the role of taxes for cross-border migration. Apart from personal characteristics determining an individual's mobility and job opportunities at home and abroad as such, net wages are clearly a key factor for the migration decision. For instance, achieving a successful career within a multinational firm is often only possible when accepting positions abroad. In any case, a fairly large variance in personal income tax rates across countries at different income brackets renders the gross wage not quite informative about a worker's net income at home and abroad. And this is where tax rates as such but also other instruments related to the tax system (such as social security contributions, etc.) - altogether, we may refer to them as the effective tax burden - come into play as possibly likely determinants of flows of migrants and expatriates.

Data suggest that countries differ remarkably with regard to the income tax burden on highly skilled workers. In particular, this is the case through high personal income tax rates and the personal income tax progression between average income earners and ones with a particularly high income (we choose a value of $500 \%$ of the average income to shed light on the matter). ${ }^{1}$ We claim that personal income tax rates are responsible not only for the investment in human capital but also the location thereof across borders, hence, skilled labor migration.

The empirical question we focus on here is to which extent personal income taxation influences migration decisions of individuals with above average skills. We shed light on this matter in a cross-section of country-pairs. More specifically, we follow the Taxing Wages Approach of the OECD (see Heady, 2004) to determine the average effective tax burden on labor which includes state and local income taxes as well as social security contributions. This approach allows decomposing countries' tax profiles into the component borne by employers and the one borne by employees. Specifically, we compute the tax wedge for a single employee earning

\footnotetext{
${ }^{1}$ In this paper we focus on the benchmark income tax burden levied by a country on well-paid labor. It is well known that some countries (e.g., Austria, Belgium, Canada, Denmark, Finland, France, Japan, Netherlands, New Zealand, Norway, and United Kingdom) explicitly provide special treatment for expatriates (see OECD, 2005). However, a detailed analysis of the latter is beyond the scope of this paper, since the country sample used our empirical analysis is by far larger than what information on special tax treatment of expatriates is available for.
} 
$100 \%$ and $500 \%$ of the average wage in the manufacturing sector for 49 economies. Besides average tax levels, we also determine the role of a tax system's degree of labor tax progressivity. Using the obtained effective tax rates and data on inward migration of skilled workers into OECD countries by country of origin for the year 2002, we obtain a number of interesting results. First, a higher resident-to-source country differential of effective tax burden on individuals earning the average wage is associated with a larger number of migrants into the resident country. Second, a higher resident-to-source country differential in the personal income tax progressivity is likewise associated with a larger number of skilled migrants into the resident country. Hence, empirical evidence provides support for our claim and suggests that politicians - at least in the developed economies - should account for the role of personal income tax policy for the location of knowledge-capital.

The remainder of the paper is structured as follows. Section 2 reviews the literature on migration of highly-skilled workers as well as that on the impact of taxes on migration. Section 3 presents the OECD's Taxing Wages Approach we rely upon and provides descriptive statistics on the effective taxation of individuals in our sample of countries. The findings from the empirical analysis of the impact of labor taxes on migration are summarized in Section 4. Finally, Section 5 concludes with a summary of the most important findings.

\section{Review of the Empirical Literature}

Among the papers which markedly influenced the literature on migration are the seminal contributions by Borjas $(1987,1994)$, who introduced the concept of 'selfselection' in migration theory. One of the key hypotheses from self-selection theory is that poor countries with an uneven wage distribution will face a 'negative selection' of immigrants such that individuals with below-average skills are most likely to migrate. The opposite is true for rich countries, where a 'positive selection' of immigrants mainly leads to a migration of workers with above-average skill level. One of the major assumptions Borjas' analysis relies upon, is that migration costs do not differ among skill levels. However, Chiquiar and Hanson (2005) provide evidence that migration costs do differ among skill groups and show that positive selection of migrants even occurs in poor countries such as Mexico. Thus, the recent empirical literature provides increasing support for the 'positive selection' of migrants and, hence, cross-border flows of skilled workers (see Chiswick, 1999; Liebig and SousaPoza, 2004; and Grogger and Hanson, 2008).

Another aspect highlighted in the literature relates to the so-called 'positive sort- 
ing' of migrants. According to Grogger and Hanson (2008), highly skilled emigrants are more likely to migrate to countries with higher rewards to skilled-relative-tounskilled labour. In the context of the present study, this positive sorting is not only concerned with the difference between gross wage rates in the resident and source countries, but also with the difference in the respective personal income tax burden, since this measure affects net wages.

With regard to the nexus of personal income taxation and migration, a number of studies directly or indirectly address this issue. However, previous work does not focus on international migration but on the location of inhabitants in Switzerland. For instance, the studies by Kirchgässner and Pommerehne (1996) and Feld and Kirchgässner (2001), suggest that income taxation influences the spread of people with high incomes across Swiss cantons. However, rather than considering migration itself, the aforementioned work assesses the nexus between income taxation and location of tax payers in general. Moreover, this work does not relate to income taxation and the location (or migration) of highly skilled workers but rather on the spatial location of workers in different income tax brackets.

The aim of our research is complementary to the one referred to in the previous paragraph. Rather than considering the spread of workers within countries, we focus on the role played by income taxation for migration flows across international borders. And in particular, we consider the role played by personal income taxation for the flows and stocks of highly skilled migrants as well as expatriates.

\section{The Computation of Effective Taxes on Labour}

A prerequisite for our empirical analysis is information on effective personal income tax rates for different income brackets. For this, we compute the effective tax burden on individuals earning $100 \%$ and ones earning $500 \%$ of the average wage in the manufacturing sector for 49 countries in the year 2002 (see OECD, 2002; and Heady, 2004). ${ }^{2}$ Accordingly, the average effective personal income tax burden borne by an employee (ITE) is defined as the ratio of the labor income tax $\left(T^{L}\right)$ plus social security contributions paid by the employee $\left(T^{S E 1}\right)$ and the overall gross wage

\footnotetext{
${ }^{2}$ The countries included in our data-set are the following: Argentina, Austria, Belgium, Brazil, Bulgaria, Canada, China, Colombia, Croatia, Cyprus, Czech Republic, Denmark, Estonia, Finland, France, Germany, Greece, Hungary, Iceland, India, Indonesia, Ireland, Italy, Japan, Latvia, Lithuania, Luxembourg, Macedonia, Malta, Mexico, Netherlands, Norway, Peru, Poland, Portugal, Romania, Russia, Slovak Republic, Slovenia, South Korea, Spain, Sweden, Switzerland, Thailand, Turkey, Ukraine, United Kingdom, United States, Uruguay.
} 
$(w)$ plus the employer's contributions $\left(T^{S E 2}\right)$. The effective tax burden borne by the employer (ITR) is defined as the ratio between the employer's social security contributions $\left(T^{S E 2}\right)$ and the overall labor cost to the employer which includes the gross wage $(w)$ and the aforementioned contributions $\left(T^{S E 2}\right)$. Hence, we have

$$
I T E=\frac{T^{L}+T^{S E 1}}{w+T^{S E 2}} ; I T R=\frac{T^{S E 2}}{w+T^{S E 2}} .
$$

These two measures together make up the overall average effective tax burden $\left(T^{A}\right)$ :

$$
T^{A}=\frac{T^{L}+T^{S E 1}+T^{S E 2}}{w+T^{S E 2}} .
$$

In particular, we use information from OECD (2002), PriceWaterhouseCoopers (PWC), and the International Bureau of Fiscal Documentation (IBFD) for the computation of ITE and ITR. For instance, the following numbers for Croatia in 2002 lead to an effective average tax rate on labor of $39.7 \%$ in that country.

Overview: Average effective tax rates on labor in Croatia

\begin{tabular}{ll}
\hline 1. Gross earnings & 7282.1 \\
2. Ded. for social sec. contributions $(=7)$. & 1500.1 \\
3. Personal Allowance & 1898.7 \\
4. Taxable income $(=1-2-3)$ & 3883.2 \\
5. Tax liability & 590.7 \\
6. State and local income taxes & 53.2 \\
7. Employee soc. sec. contributions $(=20.6 \%$ of 1.$)$ & 1500.1 \\
8. Employer soc. sec. contributions $(=17.1 \%$ of 1.$)$ & 1243 \\
9. Effective average tax rate $(=(5 .+6 .+7 .+8) /.(1 .+8))$. & $\mathbf{3 9 . 7} \%$
\end{tabular}

Apart from this, the progressivity of the personal income tax system is an important determinant of net wages, especially, the ones of high-skilled workers. To account for the fact that high-skilled workers will, on average, earn relatively high wages, we use the progression of the personal income tax system between $100 \%$ $(\operatorname{ITE}(100))$ and $500 \%(\operatorname{ITE}(500))$ of the average wage in percent in the manufacturing sector:

$$
I T P_{500 \_100}=\frac{\operatorname{ITE}(500)-\operatorname{ITE}(100)}{\operatorname{ITE}(100)} .
$$

Obviously, a stronger progressivity of a country's personal income tax system in the higher income brackets is reflected by a higher value of $I T P_{500 \_100}$. 
As mentioned above, we compute these effective tax rates for 49 countries. Then, we merge them onto a data-set of bilateral flows of skilled workers and stocks of expatriates from these countries into OECD countries. Ultimately, we then account for the difference in personal income tax rates of workers with an average income between the resident and the source country as one determinant of bilateral skilled worker migration flows or stocks of expatriates. Moreover, we account for the difference in the progressivity of the tax system as a separate determinant of these flows or stocks.

In the data at hand, the largest difference in the employee-borne average personal income tax rate between the resident country and the source country-namely one of 40.8 percentage points - pertains to emigrants from Mexico into Denmark. Other large values for the resident-to-source country differential in average personal income tax rates are obtained for migration flows from Mexico to Germany (31.6 percentage points), from Slovak Republic to Denmark (28 percentage points), and from Ireland to Denmark (27.6 percentage points), respectively. A similar picture arises when looking at the difference in the tax burden on employees earning five times the average wage. There, the highest value is recorded for migration flows from Mexico to Denmark with 50.8 percentage points. A large dispersion also exists also for migration flows from Australia to Denmark, amounting to 47.9 percentage points. However, as said before we capture the progressivity of the personal income tax system by the measure $I T P_{500 \_100}$. The largest differences in the resident-to-source country progressivity of the tax system are found between Australia and Mexico with around 4 percentage points, followed by the difference between new Zealand and Mexico with 3.6 percentage points and Hungary and Mexico with 3.1 percentage points.

\section{Empirical Analysis of Personal Income Taxes as a Determinant of Skilled Migration Flows}

\section{a. Empirical Hypotheses about the Impact of Personal Income Taxation on Expatri- ates and Migration Flows}

We may formulate the following hypotheses regarding the determinants of skilled migration flows. First, we expect skilled migrants on average to flow into large countries. For instance, Bergstrand, Egger, and Larch (2008) put forward a theoretical 
model of skilled migrants where such migration flows happen through and simultaneously with bilateral flows of foreign direct investment (which favors large countries to locate in). Second, since bilateral FDI stimulates skilled migration flows and the lion's share of foreign direct investment happens within the OECD, we expect skilled migration to be higher there than elsewhere, too. Third, similar to unskilled migrants, we hypothesize geographical distance to reduce and adjacency (common land borders) and common language characteristics between countries to raise skilled

migration flows. Fourth, similar to other migrants, we expect skilled ones to enter countries where the expected reference wage (in this case, for high income earners) is high relative to the source country. Fifth, in contrast to less skilled migrants, the aggregate unemployment rate should be fairly unimportant for skilled migrants' choice of the country of residence.

Given these economic fundamentals, we expect the resident-to-source-country tax differential to affect skilled migration flows negatively, irrespective of whether we envisage employer-borne or employee-borne taxes. In particular, we would expect a high rate of progression of the personal income tax rate in the residence country relative to the source country to reduce migration flows. It is the task of the subsequent section to assess these hypotheses.

\section{b. Specification and Data}

The empirical models estimated below employ stocks of expatriates and, alternatively, flows of skilled migrants between country-pairs as the dependent variables. Skilled migrants are workers with either secondary or, alternatively, tertiary education. The corresponding data are made available by the OECD through the Database on Immigration and Expatriates. The data are cross-sectional in nature and for the year 2002 .

With regard to personal income tax parameters, the aforementioned three variables enter the specification: the resident-to-source country employee-borne as well as the employer-borne personal income tax differential (as a fraction of income) for the average wage earner, and the differential of the tax progression of the employeeborne part in percent between the $500 \%$ and the $100 \%$ wage bracket in manufacturing.

Apart from data on personal income tax rates, the set of explanatory variables consists of two blocs of determinants. First, it includes source and destination country labor market and demand variables. For instance, GDP enters as a measure of country size (taken from the World Bank's World Development Indicators 2007). GDP is an indirect measure of labor market size (i.e., labor demand and supply 
as well as the matching probability of workers with firms). Furthermore, we use unemployment rates, indicating a possible deterrent to migration flows (also from the World Development Indicators 2007). However, we should expect unemployment to be much less important for skilled migration flows or expatriates than for migration flows as such. Finally, we include wages of workers in manufacturing (collected from OECD, 2002, and United Nations' online-database on Wages in Manufacturing). We have information about the average gross wage by country. Beyond that, we know the wage at other moments of the distribution, for instance, the one at 500 percent of the average wage. In the regressions presented here, we employ the resident-tosource country high wage (at five times the average) differential in manufacturing in most of the regressions. Yet, the availability of alternative moments of the wage distribution is still important to determine the personal income tax schedule at different moments of the income distribution.

Second, we employ data associated with barriers to or the facilitation of crossborder migration flows of skilled workers or stocks of expatriates. In particular, these are the log of bilateral distance between two countries' capitals, a common land border dummy variable, a dummy variable for common official language in the resident and the source country, and a dummy variable which is one whenever both the resident and the source country are members of the OECD and zero else. The distance, border, and language are from the geographical database made publicly available by the Centre d'Études Prospectives et d'Informations Internationales (CEPII).

\section{c. Estimation Results}

Econometrically, we employ Poisson and negative binomial pseudo maximum likelihood model estimation to take care of zero bilateral expatriates and skilled migration flows (see Cameron and Trivedi, 2005). Estimates of the variance-covariance matrix are based on Eicker-White estimates which are robust to heteroskedasticity of arbitrary form. We report parameter estimates and model characteristics for the negative binomial model in Table 1 and marginal effects of the tax parameters of interest in Table 3. The corresponding results for the Poisson model can be found in Tables 2 and 4.

$$
<\text { Tables } 1-4>
$$

First of all, the results in Table 1 suggest that the residuals of the estimated specification are characterized by over-dispersion which is highly significant. Hence, 
the negative binomial pseudo maximum likelihood model in Table 1 seems better suited for estimation than the Poisson model in Table 2. The covariates are jointly significant in either model. Many of the estimated parameters are significantly different from zero, especially, with the negative binomial model. Interestingly, the magnitude of the coefficients is quite similar across the dependent variables in use, expatriates or migrants with tertiary or secondary education.

All of the personal income tax parameters of interest are negative and significantly different from zero in Table 1 . The results indicate that skilled migrants or expatriates go less likely into a country if personal income tax rates (or their progression) are relatively high as compared to the country of origin. The parameters of the tax variables of interest are also negative in Table 2, but income tax progression does not contribute significantly to explain migration in the Poisson model. However, as said before, the Poisson model is less suited than the negative binomial model with the data at hand due to over-dispersion of the residuals.

The other covariates enter with the expected sign in Table 1 and they have similar effects in Table 2. A higher wage for well-paid workers (500 percent of the average wage in the country) in the resident relative to the source country increases skilled migration and so does GDP (although market size seems less important here than wages). Unemployment rates enter positively, which seems counter-intuitive. However, we would generally expect unemployment to be relatively unimportant for skilled employment as well as expatriates or migrants relative to that of unskilled workers. According to the remaining covariates, expatriates as well as skilled migrants mainly tend to go into non-adjacent yet not too distant countries (see the negative signs of both the distance and the contiguity parameters). The number of expatriates and skilled migration is higher among OECD countries and economies with a common official language.

Since our emphasis is on the role of personal income taxation for migration, let us focus on these variables now. While Tables 1 and 2 provide first insights into the role of personal income taxation for migration and expatriation, they do not allow for an inference of their quantitative effect. Tables 3 and 4 provide marginal effects of these variables for the negative binomial and the Poisson models. Notice that the distributional assumptions are different between these models. So it is not surprising that the magnitude of the marginal effects differs between the two approaches. In general, the marginal effects of the personal income tax rates are larger in Table 3 than in Table 4. Quantitatively, income tax progression from the average labor income to the tax bracket of an income of five times the average seems more important than taxation of the average income. This seems plausible when focusing on expatriates or skilled migrants. However, the effect is only marginally significant 
(hence, the confidence interval around the point estimate is large) with expatriates. Otherwise, the employee-borne part of taxation exerts a stronger negative impact on cross-border flows of workers than the employer-borne one.

As an alternative to the negative binomial and Poisson models, we also estimate a Heckman (1979) selection model. The latter uses an indicator variable which is set to one for non-zero bilateral expatriates or skilled migration flows and zero else. The selection equation is allowed to be correlated with an outcome equation for positive stocks of expatriates or flows of skilled migrants. ${ }^{3}$ In the outcome equation we use the $\log$ of expatriates or skilled migrants as dependent variables.

$$
<\text { Tables 5-6 > }
$$

Table 5 summarizes the parameter estimates for both the selection and outcome equations for the three dependent variables in use. According to the selection equation estimates, a higher resident-to-source country personal income tax progression reduces the probability that a positive number of expatriates is observed. With skilled migrants, especially a higher level of personal income taxation for average workers reduces the likelihood of positive skilled migration flows. The magnitude of the parameters of the personal income tax variables in the outcome equations is similar to that in Tables 1 and 2.

Table 6 summarizes marginal effects under Heckman model estimation. As said before, the elasticities are similar in Table 5 as compared to Tables 1 and 2. The marginal effects in Table 6 (expressed as elasticities) are slightly higher than in the negative binomial model. To see this, multiply the elasticities in Table 6 with the average number of expatriates or skilled migrants summarized in Table 7 of the Appendix. However, the relative magnitude of the impact of income tax progression and exmployee- as well as employer-borne tax rate differentials is similar to the one in Tables 3 and 4 . Overall, the conclusions drawn from fairly different econometric models for expatriates and skilled migrants seem quite robust.

\footnotetext{
${ }^{3}$ In contrast to the pseudo maximum likelihood models in Tables 1 and 2, Heckman's model assumes a different data-generating process for zero versus non-zero outcomes and, even more importantly, it assumes that selection into positive outcomes is correlated with the equation determining the level of outcomes.
} 


\section{Concluding Remarks}

This paper uses a large data-set on labor income taxation among 49 economies to consider its impact on the stocks of expatriates and flows of skilled migrants at the bilateral level. We apply the OECD's Taxing Wages Approach to a set of OECD and non-OECD countries and provide descriptive evidence for the nexus between labor taxation and migration of well-paid or skilled workers.

We then formulate parsimonious specifications to estimate the impact of three variables capturing the role of labor taxation for cross-border flows of workers: employee- and employer-borne tax rates for average income earners, and the progressivity of the employee-borne tax rates at high income brackets (between the average and five times the average wage). Econometrically, we employ count data and sample selection models to respect the problem of zero-inflation with data on expatriates and skilled migrants at the country-pair level.

The findings suggest that - among the considered income tax variables - the progressivity of the tax system at high income brackets is quantitatively the most important component for expatriates or migration. The second most important indicator are employee-borne personal income tax rates for average personal incomes. Employer-borne tax rates are the least important element among the three when it comes to explain expatriates or migration flows among the considered 49 countries. 


\section{Appendix}

Table 7 contains summary statistics for the dependent variables in use: the stock of expatriates and flows of migrants with tertiary and secondary education, respectively. Table 8 summarizes the descriptive statistics for the personal income tax variables as well as the other control variables included in the empirical models.

$<$ Tables 7-8 > 


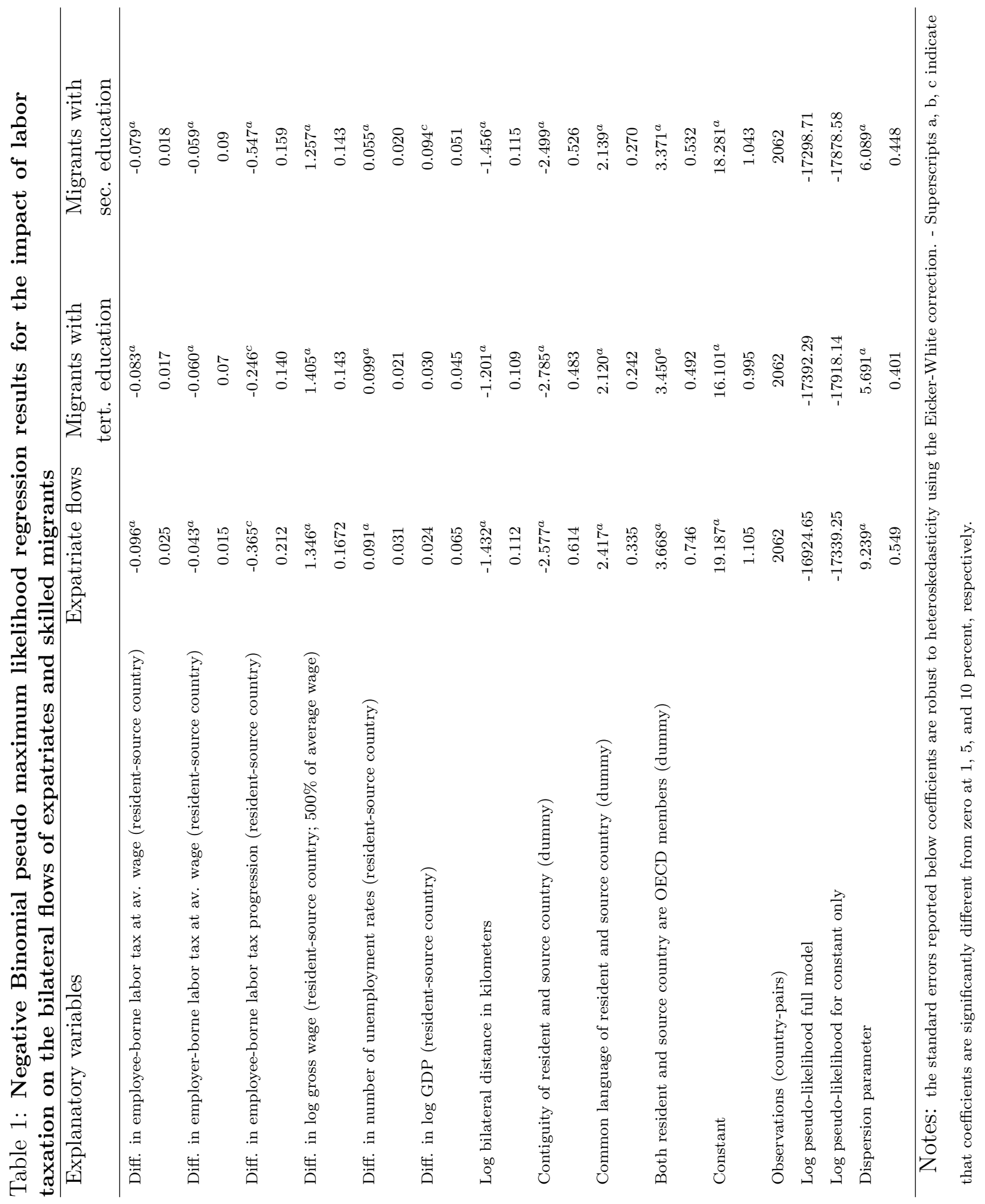




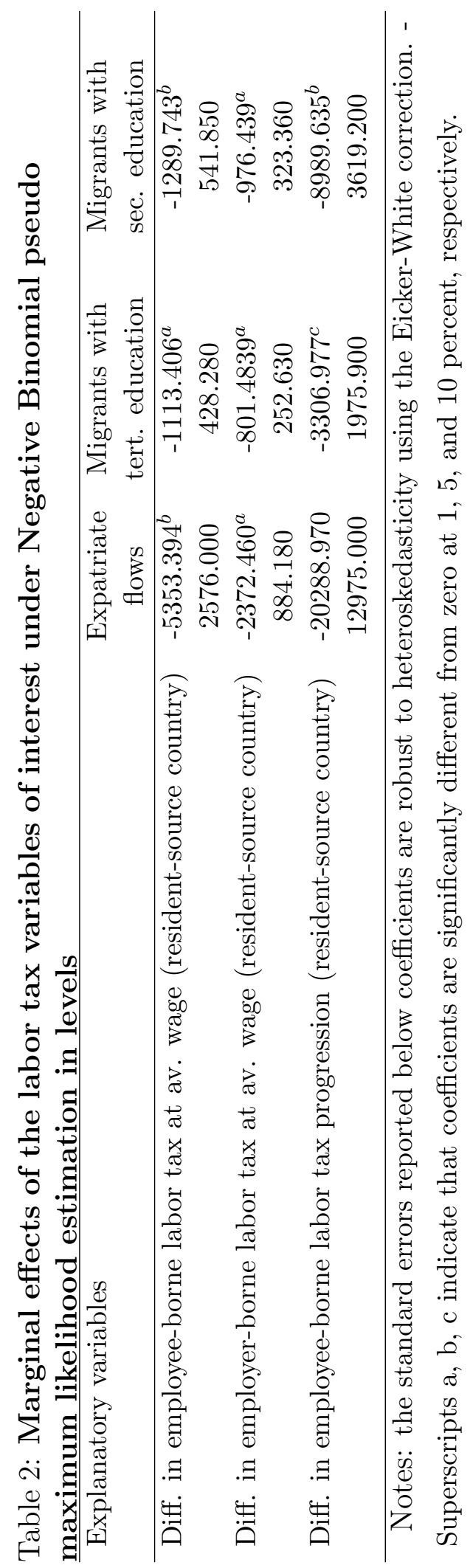




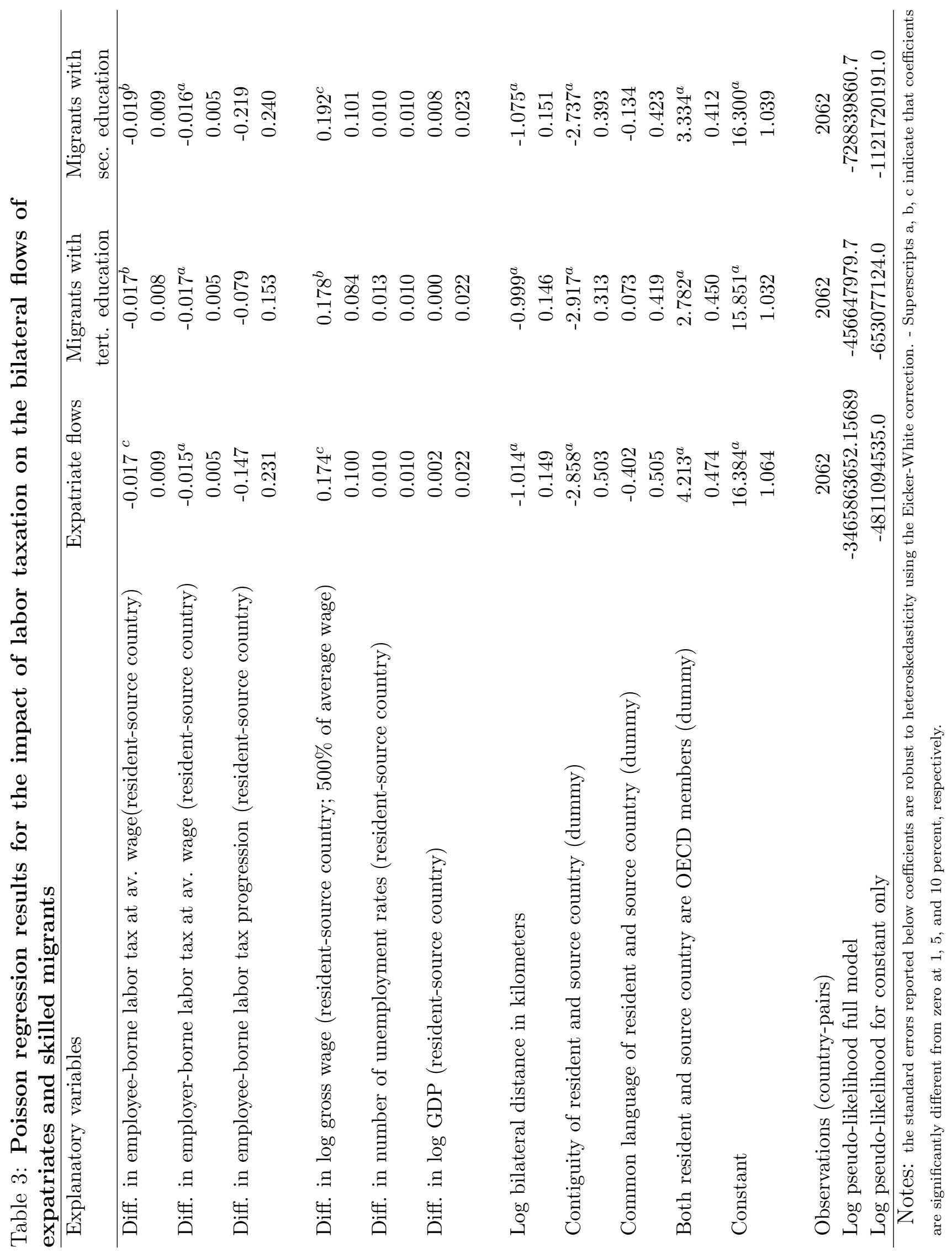




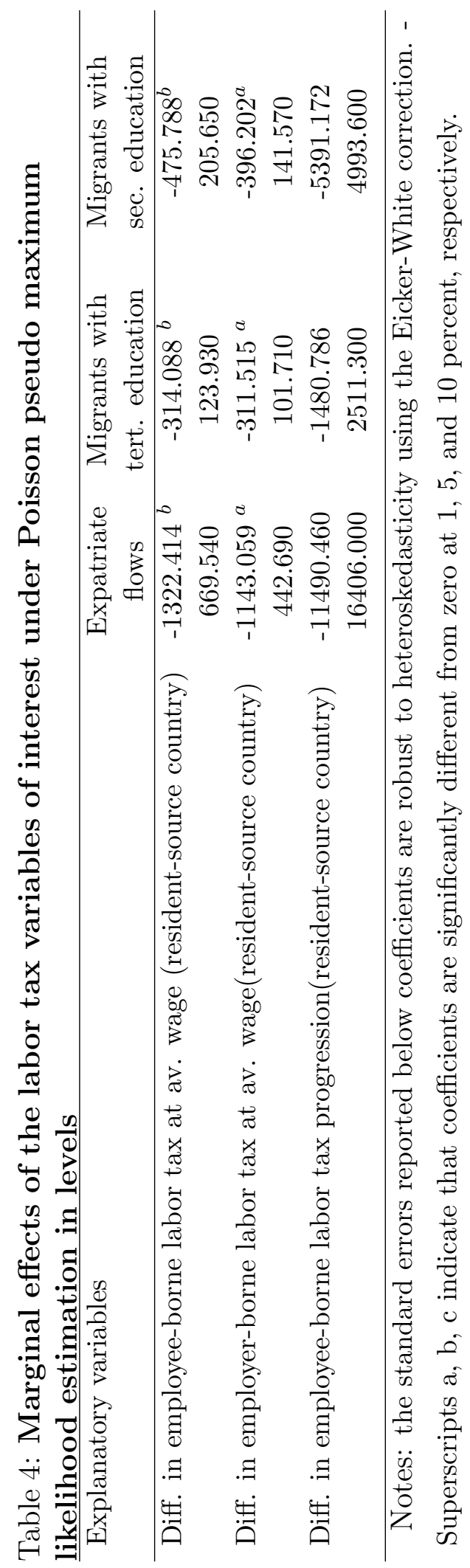




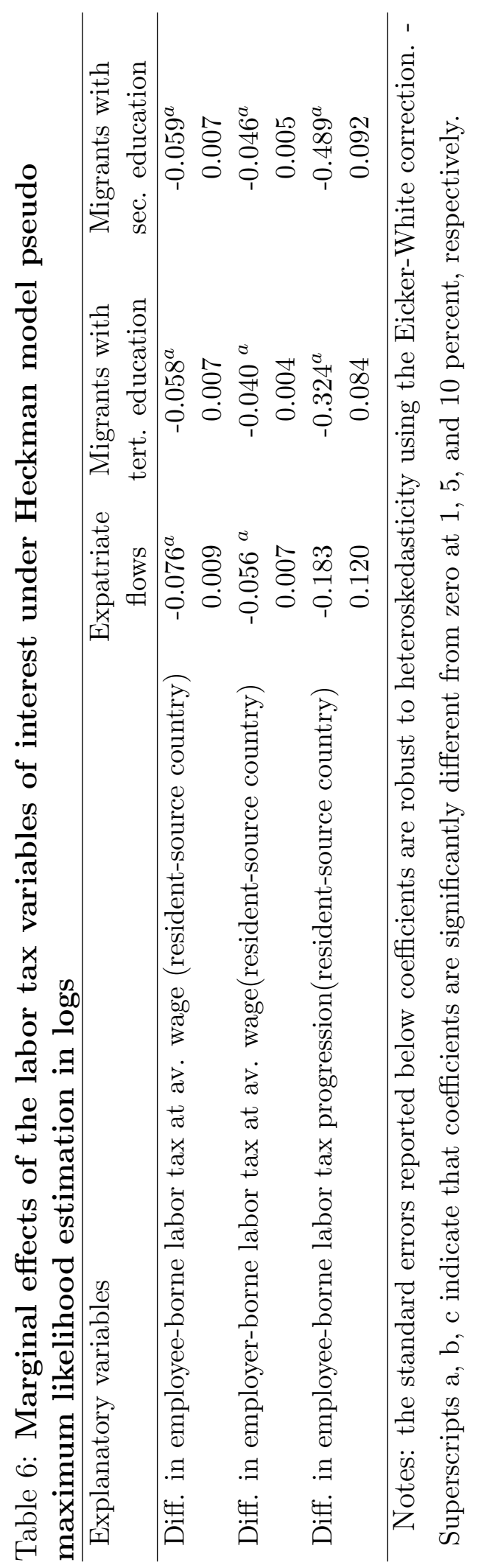




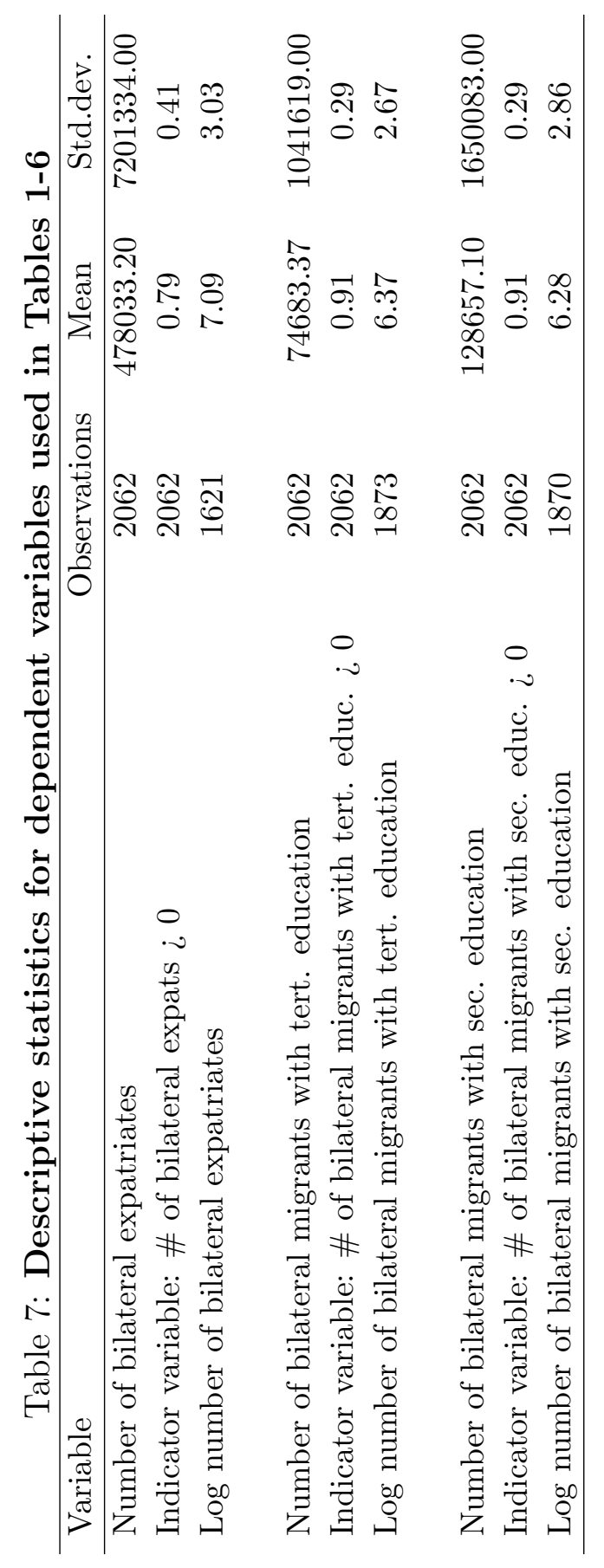




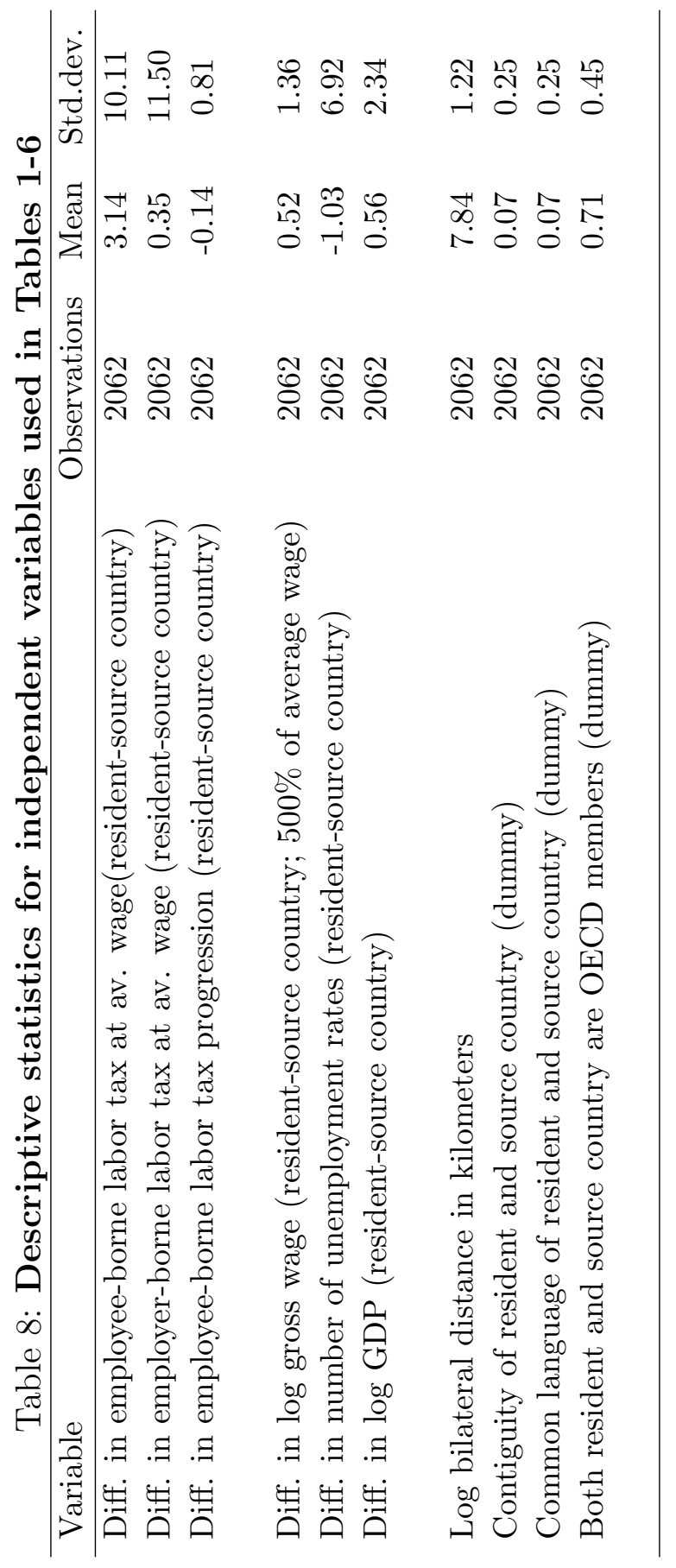




\section{References}

Bergstrand, J., P.Egger and M. Larch (2008), 'The New Expats: Economic Determinants of Bilateral Expatriate, FDI, and International Trade Flows', unpublished manuscript, University of Notre Dame.

Borjas, G. (1987), 'Self-Selection and the Earnings of Immigrants', American Economic Review, 77, 4, 531-553.

Borjas, G. (1994), 'The Economics of Immigration', Journal of Economic Literature, 32, $4,1667-1717$.

Cameron, A.C. and P.K. Trivedi (2005), Microeconometrics: Methods and Applications (New York: Cambridge University Press).

Chiquiar, D. and G.H. Hanson (2005), 'International Migration, Self-Selection, and the Distribution of Wages - evidence from Mexico and the United States', Journal of Political Economy, 113, 2, 239-281.

Chiswick, B.(1999), 'Are Immigrants Favorably Self-Selected?', American Economic Review, 89, 2, 181-185.

Feld, L. and G. Kirchgässner (2001), 'Income tax competition at the state and local level in Switzerland', Regional Science and Urban Economics, 31, 2-3, 181-213.

Grogger, J. and G.H. Hanson (2008), 'Income maximization and the selection and sorting of international migrants', NBER Working Paper 13821.

Heckman, J. (1979), 'Sample Selection Bias as a Specification Error', Econometrica, 47, $1,153-162$.

Heady, C.(2004), "The "Taxing Wages" Approach to Measuring the Tax Burden on Labor', in P. B. Sorensen (ed.), Measuring the Tax Burden on Capital and Labor (Munich: CESifo).

International Bureau of Fiscal Documentation (IBFD) (2002), European Tax Handbook (Amsterdam: International Bureau of Fiscal Documentation).

Liebig, T. and A. Sousa-Poza (2004), 'Migration, Self-Selection and Income Inequality: An International Analysis', Kyklos, 57, 125-146.

Kirchgässner, G. and W.W. Pommerehne (1996), 'Tax Harmonization and tax competition in the European Union: Evidence from Switzerland', Journal of Public Economics, 60, 3, 351-371. 
Organisation for Economic Co-operation and Development (OECD) (2002), Taxing Wages 2002-2003, (Paris: Organisation for Economic Cooperation and Development).

Organisation for Economic Co-operation and Development (OECD) (2005), Trends in International Migration, (Paris: Organisation for Economic Cooperation and Development).

Organisation for Economic Co-operation and Development (OECD) (2007), Recent Trends in International Migration, (Paris: Organisation for Economic Cooperation and Development).

World Bank (2007), World Development Indicators, (Washington: World Bank). 


\section{CESifo Working Paper Series}

for full list see www.cesifo-group.org/wp

(address: Poschingerstr. 5, 81679 Munich, Germany, office@cesifo.de)

2401 Torben M. Andersen and Joydeep Bhattacharya, On Myopia as Rationale for Social Security, September 2008

2402 Fabienne Llense, French CEO Compensations: What is the Cost of a Mandatory Upper Limit?, September 2008

2403 Valentina Bosetti, Carlo Carraro, Alessandra Sgobbi and Massimo Tavoni, Delayed Action and Uncertain Targets. How Much Will Climate Policy Cost?, September 2008

2404 Robert G. Chambers, Rolf Färe, Shawna Grosskopf and Michael Vardanyan, Generalized Quadratic Revenue Functions, September 2008

2405 Leonidas Enrique de la Rosa, Overconfidence in a Career-Concerns Setting, September 2008

2406 Marcus Drometer and Johannes Rincke, The Design of Political Institutions: Electoral Competition and the Choice of Ballot Access Restrictions in the United States, September 2008

2407 Markku Lanne and Helmut Lütkepohl, Stock Prices and Economic Fluctuations: A Markov Switching Structural Vector Autoregressive Analysis, September 2008

2408 Thomas L. Brewer, International Energy Technology Transfers for Climate Change Mitigations, September 2008

2409 Alexander Kemnitz, Native Welfare Losses from High Skilled Immigration, September 2008

2410 Xavier Vives, Strategic Supply Function Competition with Private Information, September 2008

2411 Fabio Padovano and Roberto Ricciuti, The Political Competition-Economic Performance Puzzle: Evidence from the OECD Countries and the Italian Regions, September 2008

2412 Joan Costa-Font and Mireia Jofre-Bonet, Body Image and Food Disorders: Evidence from a Sample of European Women, September 2008

2413 Thorsten Upmann, Labour Unions - To Unite or to Separate?, October 2008

2414 Sascha O. Becker and Ludger Woessmann, Luther and the Girls: Religious Denomination and the Female Education Gap in $19^{\text {th }}$ Century Prussia, October 2008

2415 Florian Englmaier and Stephen Leider, Contractual and Organizational Structure with Reciprocal Agents, October 2008 
2416 Vittorio Daniele and Ugo Marani, Organized Crime and Foreign Direct Investment: The Italian Case, October 2008

2417 Valentina Bosetti, Carlo Carraro, Alessandra Sgobbi and Massimo Tavoni, Modelling Economic Impacts of Alternative International Climate Policy Architectures. A Quantitative and Comparative Assessment of Architectures for Agreement, October 2008

2418 Paul De Grauwe, Animal Spirits and Monetary Policy, October 2008

2419 Guglielmo Maria Caporale, Christophe Rault, Robert Sova and Anamaria Sova, On the Bilateral Trade Effects of Free Trade Agreements between the EU-15 and the CEEC-4 Countries, October 2008

2420 Yin-Wong Cheung and Daniel Friedman, Speculative Attacks: A Laboratory Study in Continuous Time, October 2008

2421 Kamila Fialová and Ondřej Schneider, Labour Market Institutions and their Effect on Labour Market Performance in the New EU Member Countries, October 2008

2422 Alexander Ludwig and Michael Reiter, Sharing Demographic Risk - Who is Afraid of the Baby Bust?, October 2008

2423 Doina Maria Radulescu and Michael Stimmelmayr, The Welfare Loss from Differential Taxation of Sectors in Germany, October 2008

2424 Nikolaus Wolf, Was Germany ever United? Evidence from Intra- and International Trade 1885 - 1933, October 2008

2425 Bruno S. Frey, David A. Savage and Benno Torgler, Noblesse Oblige? Determinants of Survival in a Life and Death Situation, October 2008

2426 Giovanni Facchini, Peri Silva and Gerald Willmann, The Customs Union Issue: Why do we Observe so few of them?, October 2008

2427 Wido Geis, Silke Uebelmesser and Martin Werding, Why go to France or Germany, if you could as well go to the UK or the US? Selective Features of Immigration to four major OECD Countries, October 2008

2428 Geeta Kingdon and Francis Teal, Teacher Unions, Teacher Pay and Student Performance in India: A Pupil Fixed Effects Approach, October 2008

2429 Andreas Haufler and Marco Runkel, Firms' Financial Choices and Thin Capitalization Rules under Corporate Tax Competition, October 2008

2430 Matz Dahlberg, Heléne Lundqvist and Eva Mörk, Intergovernmental Grants and Bureaucratic Power, October 2008

2431 Alfons J. Weichenrieder and Tina Klautke, Taxes and the Efficiency Costs of Capital Distortions, October 2008 
2432 Andreas Knabe and Ronnie Schöb, Minimum Wage Incidence: The Case for Germany, October 2008

2433 Kurt R. Brekke and Odd Rune Straume, Pharmaceutical Patents: Incentives for R\&D or Marketing?, October 2008

2434 Scott Alan Carson, Geography, Insolation, and Institutional Change in $19^{\text {th }}$ Century African-American and White Stature in Southern States, October 2008

2435 Emilia Del Bono and Daniela Vuri, Job Mobility and the Gender Wage Gap in Italy, October 2008

2436 Marco Angrisani, Antonio Guarino, Steffen Huck and Nathan Larson, No-Trade in the Laboratory, October 2008

2437 Josse Delfgaauw and Robert Dur, Managerial Talent, Motivation, and Self-Selection into Public Management, October 2008

2438 Christian Bauer and Wolfgang Buchholz, How Changing Prudence and Risk Aversion Affect Optimal Saving, October 2008

2439 Erich Battistin, Clara Graziano and Bruno Parigi, Connections and Performance in Bankers' Turnover: Better Wed over the Mixen than over the Moor, October 2008

2440 Erkki Koskela and Panu Poutvaara, Flexible Outsourcing and the Impacts of Labour Taxation in European Welfare States, October 2008

2441 Marcelo Resende, Concentration and Market Size: Lower Bound Estimates for the Brazilian Industry, October 2008

2442 Giandomenico Piluso and Roberto Ricciuti, Fiscal Policy and the Banking System in Italy. Have Taxes, Public Spending and Banks been Procyclical in the Long-Run? October 2008

2443 Bruno S. Frey and Katja Rost, Do Rankings Reflect Research Quality?, October 2008

2444 Guglielmo Maria Caporale, Antoaneta Serguieva and Hao Wu, Financial Contagion: Evolutionary Optimisation of a Multinational Agent-Based Model, October 2008

2445 Valentina Bosetti, Carlo Carraro and Massimo Tavoni, Delayed Participation of Developing Countries to Climate Agreements: Should Action in the EU and US be Postponed?, October 2008

2446 Alexander Kovalenkov and Xavier Vives, Competitive Rational Expectations Equilibria without Apology, November 2008

2447 Thiess Buettner and Fédéric Holm-Hadulla, Cities in Fiscal Equalization, November 2008 
2448 Harry H. Kelejian and Ingmar R. Prucha, Specification and Estimation of Spatial Autoregressive Models with Autoregressive and Heteroskedastic Disturbances, November 2008

2449 Jan Bouckaert, Hans Degryse and Thomas Provoost, Enhancing Market Power by Reducing Switching Costs, November 2008

2450 Frank Heinemann, Escaping from a Combination of Liquidity Trap and Credit Crunch, November 2008

2451 Dan Anderberg, Optimal Policy and the Risk Properties of Human Capital Reconsidered, November 2008

2452 Christian Keuschnigg and Evelyn Ribi, Outsourcing, Unemployment and Welfare Policy, November 2008

2453 Bernd Theilen, Market Competition and Lower Tier Incentives, November 2008

2454 Ondřej Schneider, Voting in the European Union - Central Europe's Lost Voice, November 2008

2455 Oliver Lorz and Gerald Willmann, Enlargement versus Deepening: The Trade-off Facing Economic Unions, November 2008

2456 Alfons J. Weichenrieder and Helen Windischbauer, Thin-Capitalization Rules and Company Responses, Experience from German Legislation, November 2008

2457 Andreas Knabe and Steffen Rätzel, Scarring or Scaring? The Psychological Impact of Past Unemployment and Future Unemployment Risk, November 2008

2458 John Whalley and Sean Walsh, Bringing the Copenhagen Global Climate Change Negotiations to Conclusion, November 2008

2459 Daniel Mejía, The War on Illegal Drugs in Producer and Consumer Countries: A Simple Analytical Framework, November 2008

2460 Carola Frydman, Learning from the Past: Trends in Executive Compensation over the Twentieth Century, November 2008

2461 Wolfgang Ochel, The Political Economy of Two-tier Reforms of Employment Protection in Europe, November 2008

2462 Peter Egger and Doina Maria Radulescu, The Influence of Labor Taxes on the Migration of Skilled Workers, November 2008 